\title{
Satisfaction of occupational and physical therapy students during their internship program
}

\author{
Fayz S. Al Shahry', Arwa Saqr Almutairi², Ruyuf Abdulrahman Aljoufi² and \\ Roboa A. Al-Sulami² \\ ${ }^{1}$ Assistant Prof. CAMS, KSAU-HS, Consultant, Neuro Rehabilitation KAMC, Saudi Arabia, Riyadh \\ ${ }^{2}$ Student Occupational Therapy, CAMS, KSAU-HS, Saudi Arabia, Riyadh
}

\begin{abstract}
The internship year is considered to be a golden period for students' training, as they are exposed during that time to a majority of medical specialties and will gain more knowledge and clinical skills. it is the time they convert their taught information and knowledge into skills. However the quality of training and the appropriateness of environment as well as the satisfaction of trainee is a major issue. Our study aimed to assess the satisfaction about internship training of occupational and physical therapy, among interns in Riyadh. A cross-sectional study was conducted including 81 Occupational Therapy (OT) and Physical Therapy (PT) interns from King Abdulaziz Medical City (KAMC) and King Abduallah Specialized Children Hospital (KASCH) (48 females, 33 males; 41 PT, 40 OT; mean age 23.07 yrs, SD-1.17). Interns were excluded if they had a repeated rotation either due to weak performance or as disciplinary action from the department, faced problems in the department that required further investigation, and spent less than two months in the hospital. A survey previously used in Al Dammam study. It has 21 items divided across four domains that are either related to preparatory work towards internship, satisfaction, and comfort with the supervisor and internship site, attainment of intended learning outcomes, or evaluation and feedback during internship. Three interns were excluded as they spent less than two months in the hospital. Interns had a satisfaction rate of 83.05\% where PT interns had a satisfaction rate of $86.15 \%$, and OT interns had 78.50\%. Additionally, PT interns had a higher satisfaction rate than OT interns across all domains. However, the only significant difference between the two programs was on the items related to evaluation and feedback during the internship. Interns in the main hospital had a satisfaction rate of 84.15\%, whereas interns in KASCH had a satisfaction rate of 80.94\%.We found a high satisfaction rate of OT and PT interns in this study, and higher satisfaction of PT interns compared to OT interns. However, further research can be conducted using the same questionnaire to explore different hospitals in Riyadh and different region within Saudi Arabia to have an overall estimation of satisfaction rate among the PT and OT at the national level.
\end{abstract}

KEY WORDS: INTERNSHIP, OCCUPATIONAL THERAPY, PHYSIOTHERAPY, SATISFACTION

\section{ARTICLE INFORMATION:}

Corresponding Authors: shahryf@hotmail.com drshadabuddins@gmail.com

Received 30 $0^{\text {th }}$ Sep, 2018

Accepted after revision $21^{\text {st }}$ Dec, 2018

BBRC Print ISSN: 0974-6455

Online ISSN: 2321-4007 CODEN: USA BBRCBA Thomson Reuters ISI ESC / Clarivate Analytics USA

Mono of Clarivate Analytics and Crossref Indexed Journal Mono of $C R$

NAAS Journal Score 2018: 4.31 SJIF 2017: 4.196

- A Society of Science and Nature Publication, Bhopal India 2018. All rights reserved.

Online Contents Available at: http//www.bbrc.in/

DOI: $10.21786 / \mathrm{bbrc} / 11.4 / 15$ 


\section{INTRODUCTION}

Internship training is known to be one mandatory year after completing the undergraduate study where the interns are required to apply their academic (theoretical) learning to practical (clinical) experiences. The internship year is considered to be a golden period for students' training, as they are exposed during that time to a majority of medical specialties and will gain more knowledge and clinical skills, (Finucane and 0'Dowd, 2005). As stated by Davis (1990), intern training is an experiential learning which gives the students the opportunity to apply what they have learned from schools in real world situation, and it gives the interns a chance to consolidate and combine thinking and action, (Cheong et al., 2014, Sasnett and Rose, 2016; Yasser et al., 2016).

It is a valuable component of academic programs, which is beneficial for the student, employer as well as the university. Internship training has a major role in improving learning professional skills, applying what have been learned theoretically in real life, improving communication and teamwork skills, gaining more experiences which increase interns' quality to deal with different situations in the future, identifying strengths and weakness, and preparing interns' mindset for their future careers, (Hart et al., 1989; Sasnett and Rose, 2016 and Phua 2017).

Training programs might also help to improve immediate skills that could eventually improve course performances. For example, better time management, heightened initiative, and better self-discipline and an overall better self-concept (Dennis, 1996). The interns gain tremendous advantages other than the experience they obtain during their internship. This opportunity allows them to discover their areas of interest and scout about the environment. However, future professional jobs must be available for the interns in order to achieve the best possible outcomes, (Wurfel and Walter 1985, Berger, 1991; Ramus, 1997; Verney et al., 2009 and Phua 2017).

The strengths I advantages of internship confirm the importance of developing an efficient training program. Earlier studies reported that the majority of interns improved their knowledge about the field as a result of the training/internship program (Al Thukair, 2014)interns, alumni, coordinators, and supervisors of the Health Information Management and Technology (HIMT. Sufficient contact with a training coordinator may promote the benefits that interns could gain from internship (Yafang and Gongyong, 2008). The contentment of interns with the training may be a chance to raise their interests in fulltime jobs (D'abate et al., 2009). In contrast, according to Taylor (1988), "poor supervision was the most likely condition to lead to dissatisfaction with internships" (Taylor, 1988). Nelson (1994) stated that repetitious work with low freedom to test knowledge along with the high risk that accompanies insufficient feedback would relate to dissatisfaction with supervision (Nelson, 1994).

Al-Muhanna (2009), observed that the major issue facing medical and health profession interns is the gap between what is offered by the training institution and what the interns want or expect. Another problem in internship training is the stress linked with the internship year due to its importance to the interns' professional lives (Al-Muhanna, 2009). Another issue mentioned by Hannon (2000) is the lack of adequate preparation for internship. Graduates thought they haven't yet developed the acquired attitudes and skills, therefore, it was perceived as being unfair to the patient and eventually decreeing the interns' benefit from clinical training. Additionally, some stated that some clinical practices may be more effective than the ones actually used (Hannon, 2000). In one study, the lowest rate of satisfaction was given to the feedback level from the trainer as well the number of available trainers in relation to the number of students (Serwah, Sulimani, Samy, \& Serwah, 2015). In another study, interns have reported a few incidents of mistreatment especially verbal attacks (Daugherty, Baldwin, \& Rowley, 1998). Also, another study which was concerned with pharmacy interns stated that the training period in a certain area \ ward is too short (Phua et al., 2017).

Having knowledge about these issues and any other issues that may face medical and health profession interns will help in improving the interns' experience in clinical training and improving their performance. The present study was proposed to overcome the lack of data on the satisfaction of interns in occupational therapy and physical therapy about their training program. The results of the study will give insight to strengths and weaknesses and chances for improvement of the current internship programs with respect to OT and PT.

\section{METHODS}

Subjects of this study were occupational and physical therapy interns in King Abdulaziz Medical City (KAMC) and King Abduallah Specialized Children Hospital (KASCH). Institutional review board (IRB) approval was obtained before conducting the study, and informed consent was obtained from all participants before the data collection. Participants' confidentiality was strictly observed throughout the study by using an anonymous unique serial number for each subject and restricting data only to the investigators. The inclusion criteria were occupational and physical therapy interns, male and female, who passed at least one rotation of 2 months duration in the designated setting. The exclusion criteria were occupational and physical therapy interns who have had a repeated rotation either due to weak performance or as disciplinary action from the department, faced problems 
in the department that required further investigation, and spent less than two months in the hospital.

The data was collected by a structured questionnaire which measures the satisfaction of interns in the following areas: preparation, internship posting, professional skills and knowledge, and evaluation and feedback. It had been previously used in Al Dammam study, with slight modifications including questions about the duration of the internship, any conflict the interns have experienced in the current setting, and the number of passed rotations. In this questionnaire, the subjects filled out variables about their age, gender, program, a name of the hospital, and the start and end date of the internship. However, the focus of this survey was converted to fit the clinical internship program rather than NCAAA. This questionnaire, adapted from the previously mentioned study, was used in Saudi Arabia with similar objectives and subjects to this study. Therefore, this questionnaire was used to broaden the scope of measuring interns' satisfaction in KAMC and KASCH in Riyadh.

The measurement tool used was the Likert scale where a score of 0 was assigned to strongly disagree which is the lowest grading, and a score of 3 was assigned to strongly agree which is the maximum score. A score of 1 was assigned to disagree, and a score of 2 was assigned to agree. Whereas in yes/no questions at the end of the questionnaire, a score of 1 was assigned to 'yes' and a score of 2 is assigned to 'no.' At the end of the survey, the interns had the chance to write any suggestions or recommendations the could have made their internship experience better which can be used by the institution for future improvements in their internship program.

The collected data was entered into Microsoft Excel after ensuring the removal of confidential information and after being coded and cleared. It was then exported to SPSS version 22 where categorical variables were represented in frequencies and percentages, and the continuous variable was represented in mean and standard deviation. Percentages of overall satisfaction, satisfaction in each domain, satisfaction between programs, and satisfaction between hospitals were calculated. Independent t sample test was used to measure any significant difference in satisfaction between programs.

\section{RESULTS AND DISCUSSION}

\section{DEMOGRAPHICS OF PARTICIPANTS}

A total of 100 surveys were distributed, and 84 responded. 3 participants were excluded as they have spent less than two months in the hospital. 81 participants entered analysis including 40 (49.4\%) from occupational therapy program and 41 (50.6\%) from physical therapy program. 45 (55.6\%) respondents were in King Abdulaziz Medical City, 26 (32.1\%) respondents were in King Abduallah Specialized Children Hospital, and $10(12.3 \%)$ respondents were in both hospitals. Table 1 shows the detailed backgrounds of the respondents

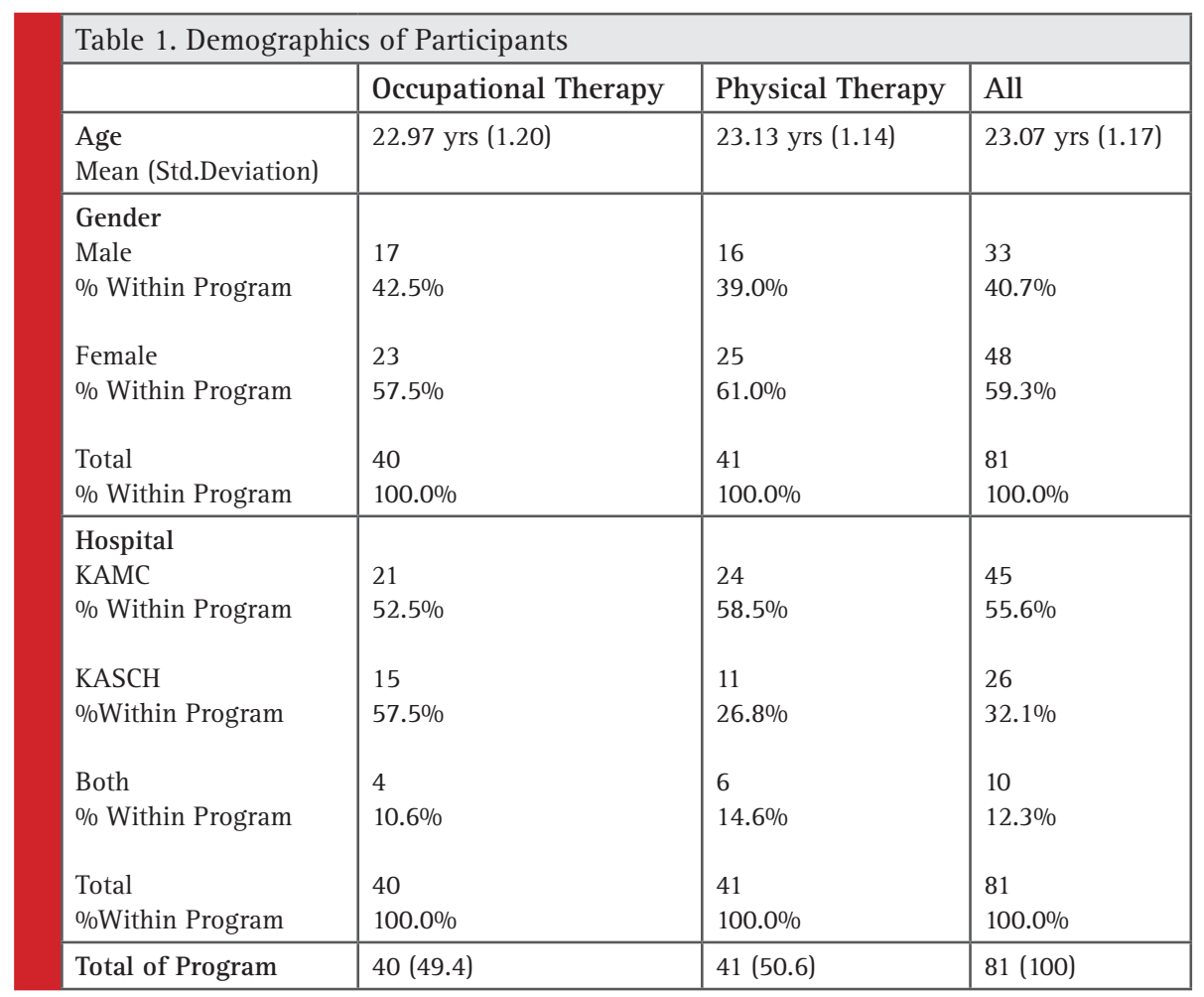




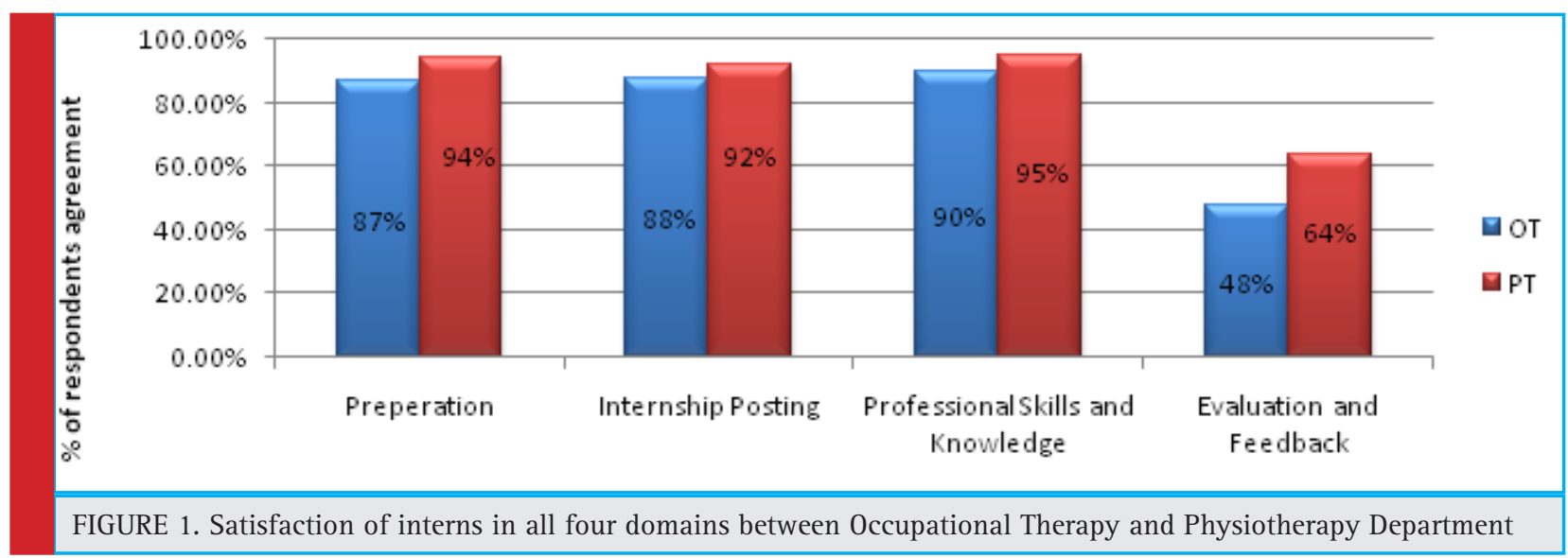

The present study was proposed to determine data on the satisfaction of interns in occupational therapy and physical therapy department in King Abdulaziz Medical City (KAMC) and King Abduallah Specialized Children Hospital (KASCH) in Saudi Arabia at Riyadh. The result shows the satisfaction rate in 4 domains (Preparation, Internship Posting, Professional Skills and Knowledge, and Evaluation and Feedback by the program) according to OT \& PT Program. PT interns had a satisfaction rate of $86.15 \%$, whereas OT interns had a satisfaction rate of 78.50\%. In comparison to each domain, PT interns had a satisfaction rate of 94\%, 92\%, 95\%, and 64\% respectively to the domains of preparation, internship posting, professional skills and knowledge, and evaluation and feedback. OT interns had a satisfaction rate of $87 \%, 88 \%, 90 \%$, and $48 \%$ respectively to the previously mentioned domains as shown in figure 1. Additionally, figure 2,3,4 and 5 shows level on each item related to preparatory work towards internship, comfort with the supervisor and internship site, attainment of intended learning outcomes and evaluation and feedback during the internship. The p-value for all domains was measured. However, the only significant difference between the programs was in the evaluation and feedback domain ( $p$-value $>0.05$ ).
Table 2 shows the detailed scoring of the survey in each of the four domains by hospitals. In the comparison between KAMC and KASCH, interns in KAMC had a satisfaction rate of $84.15 \%$, whereas interns in $\mathrm{KASCH}$ had a satisfaction rate of $80.94 \%$. The difference in some interns between KAMC and KASCH should acknowledge which may affect the precision of our estimates in this study.

This study aimed to assess the satisfaction of occupational and physical therapy interns about their internship experience in KAMC and KASCH. We asked the interns to fill out a survey with four domains and a total of 21 items. The results of this study indicate that OT and PT interns are generally satisfied with their internship experience. Items related to preparatory work towards internship, satisfaction, and comfort with the supervisor, internship site and attainment of intended learning outcomes had a high satisfaction rate of over 90\%, whereas items related to evaluation and feedback during the internship had the lowest satisfaction rate. Therefore the feedback in a regular short period is very important and considered excellent mechanism for student to rectify, (Serwah et al., 2015).

The five items with the highest agreement level include: learning new skills and knowledge during the

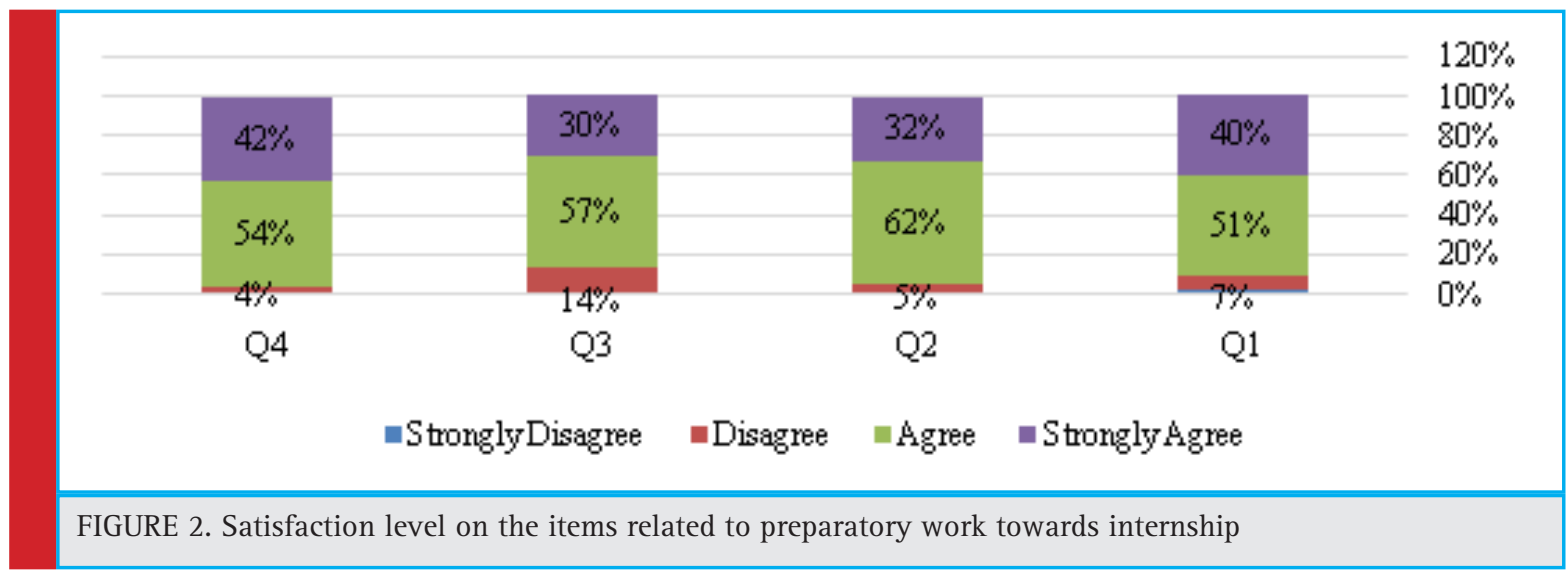




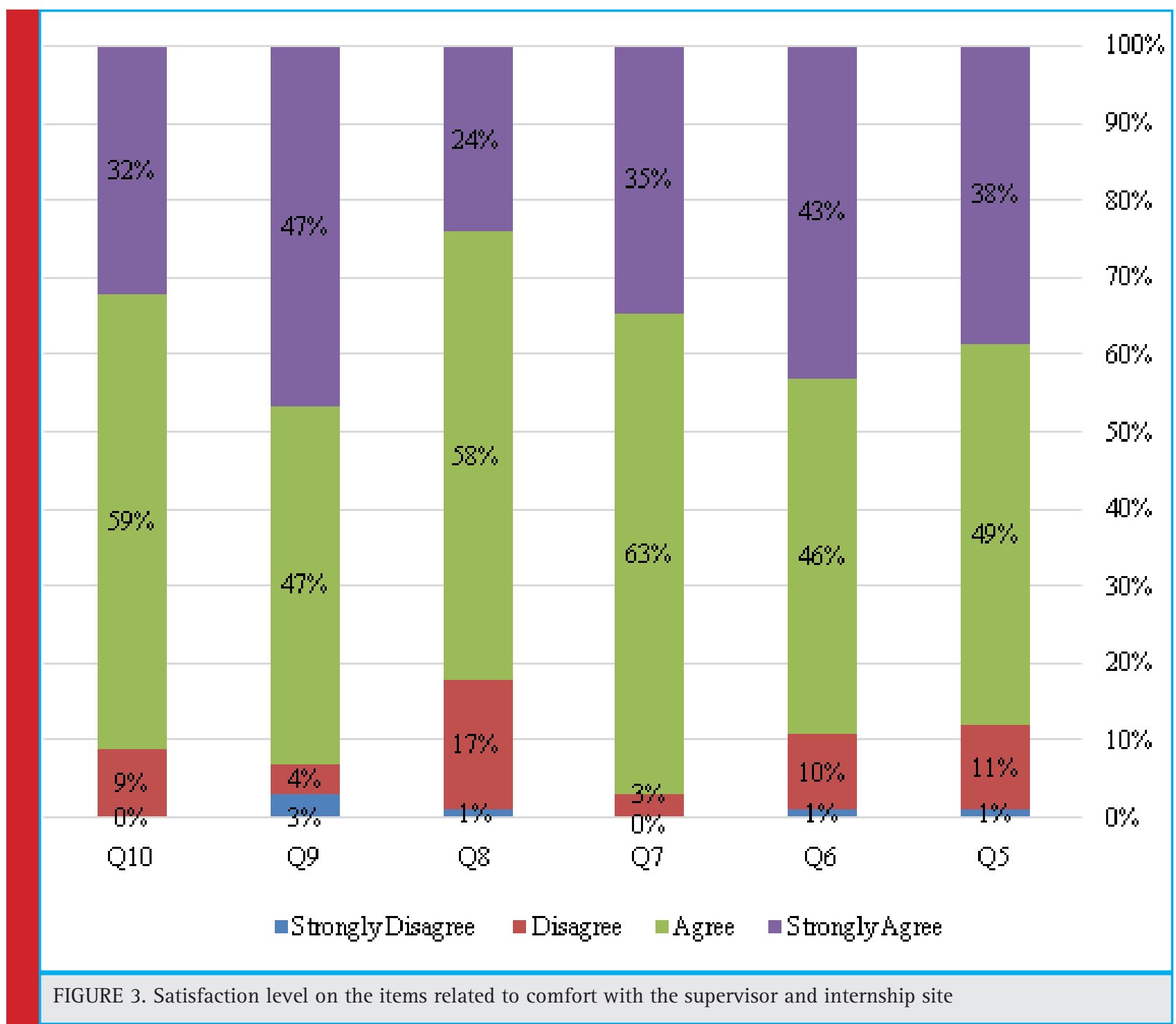

internship (item 11), the interns feeling their presence at the hospital made a positive contribution to professionals at internship site (item 7), followed by the interns gaining insight into the work environment and field of their interest (item 13), Alshomrani et al. 2016, Sasnett et al. 2016, Finucane et al. 2009). Being well prepared for the internship (item 4), developing an awareness of the areas in which the interns needed growth (item 16), and finding the internship handbook to be clear and very useful (item 2) followed by applying to the job in the hospital if an open opportunity was available (item 9).

The five items with the lowest agreement level include: being asked to prepare a report at the end of each internship rotation (item 19), having arranged meeting by the university to reflect on the internship experience (item 20), visitations from internship coordinator at field loca- tion for observation (item 17), having the opportunity to freely evaluate the experience at the hospital (item 18), and being heard and responded to when raising issues about the internship process with the internship coordinator (item 21) (Finucane et al. 2005).

PT interns were generally more satisfied than OT interns. On each domain of the survey, PT interns also had a higher satisfaction rate than OT interns. However, the only significant difference between the two programs was on the items related to the evaluation and feedback domain. This might be attributed to individual differences in the supervisors' evaluation of the interns toward the end of the internship. Furthermore, interns who had their internship in KAMC had a slightly higher satisfaction rate than interns in KASCH generally and on each domain. The only significant domain was the satisfaction and comfort of the supervisor and intern- 


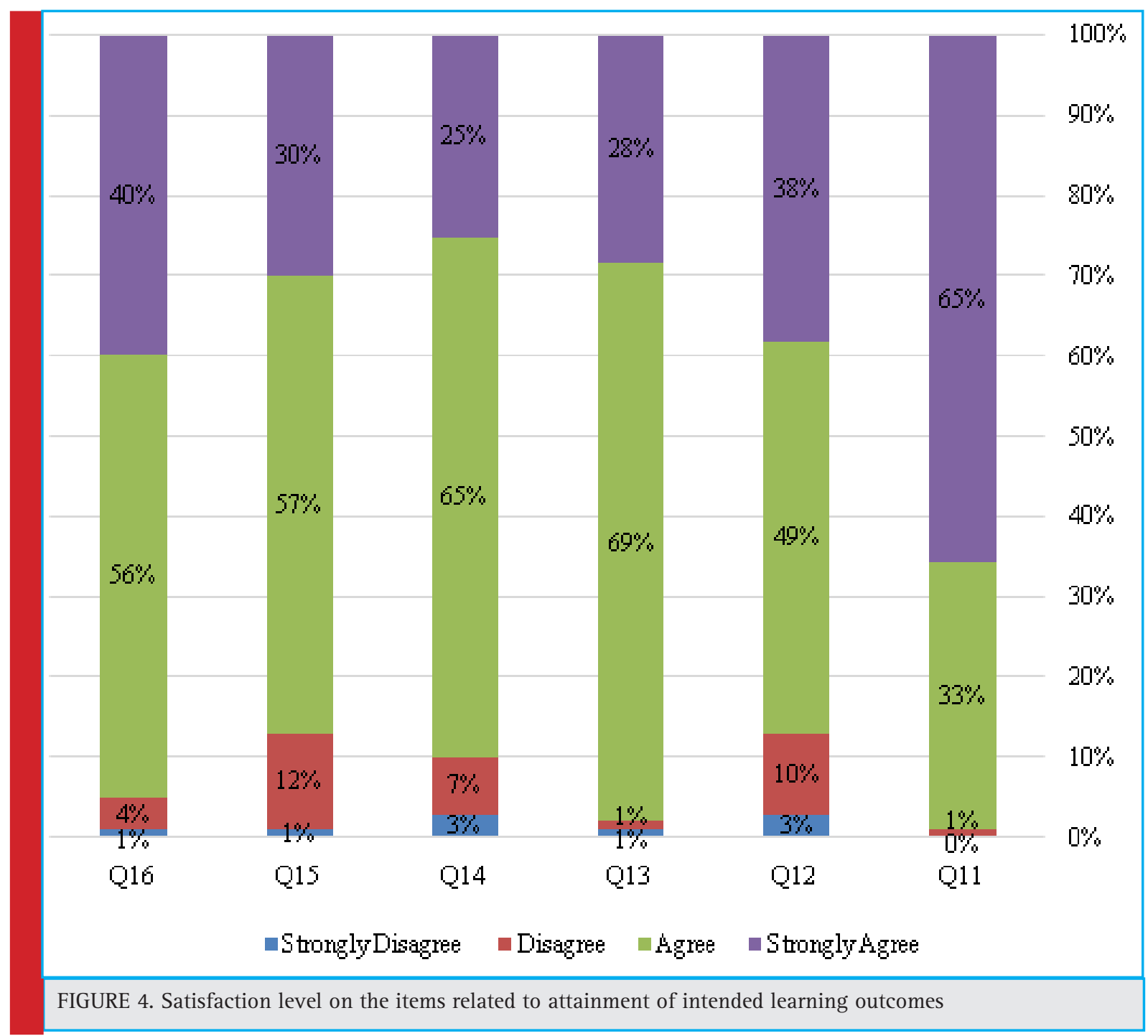

ship site,). Taylor 1988 highlighted the importance of supervision. Also, giving the interns the opportunity to choose the internship site could help in increasing their satisfaction level.

Through examining the literature, we found one study that has been carried out in Damam in which we can compare our finding to their results. Al Thukair conducted a study in 2014, at Al Dammam comparing the satisfaction in PT and HIMT interns, and found that items related to preparatory work towards internship, satisfaction, the comfort with the supervisor, the internship site, and attainment of intended learning outcomes had the highest satisfaction rate, whereas items related to evaluation and feedback during the internship had the lowest satisfaction rate which was consistent with our study, (Al Thukair 2014). This Items identified as having the lowest satisfaction rate were inconsistent with our research as not all items related to evaluation and feedback during internship were identified as having the lowest satisfaction rate.

Strengths of this study include that the data was collected from KAMC and KASCH which are tertiary care hospitals with high bed capacity and high-quality rehabilitation services that cover most patient population in the central region of Riyadh. Secondly, we collected a sample size that should be representative of all OT and PT interns in the central region of Riyadh. Thirdly, the questionnaire had been previously used in Al Dammam study by Al Thukair (2014) as a valid and a reliable questionnaire. Finally, this study, up to our knowledge, is the first study that assesses the satisfaction of OT interns, or OT and PT interns combined in Saudi Arabia. However, limitations of the study include the limited hospital sittings with no further expansion to more hospitals. Additionally, the difference in a number of interns between KAMC and KASCH should be acknowledged which may 


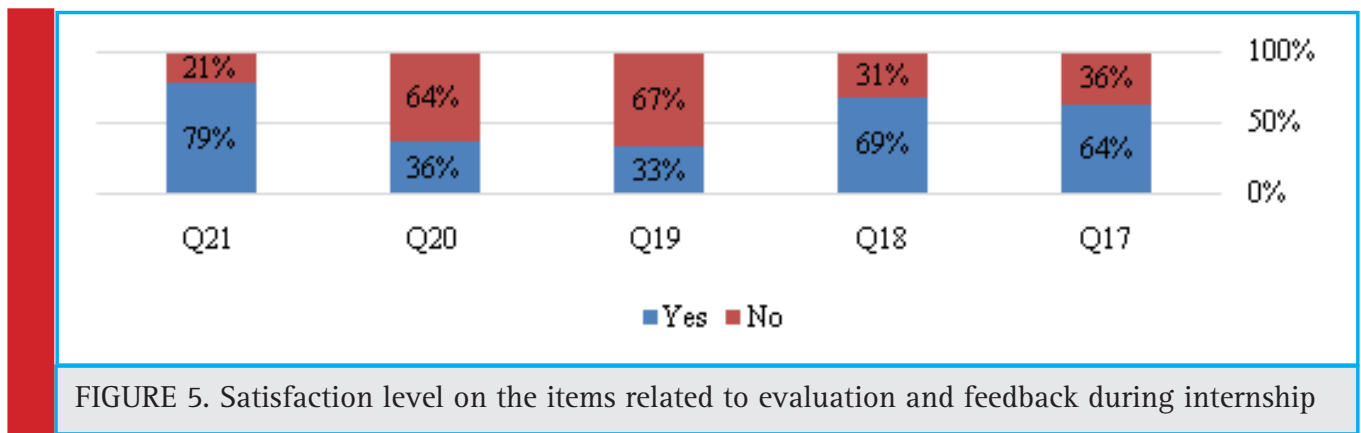

\begin{tabular}{|c|c|c|c|c|c|c|}
\hline \multicolumn{2}{|c|}{ Items } & Response & KAMC & $\mathrm{KASCH}$ & Both & Total \\
\hline \multirow{4}{*}{ Q1 } & \multirow{4}{*}{$\begin{array}{l}\text { Preparation: } \\
\text { The orientation for internship } \\
\text { increased my level of comfort } \\
\text { with the process, and, with my } \\
\text { responsibilities as an intern. }\end{array}$} & Strongly Disagree & $2(4.4 \%)$ & $0(0.00 \%)$ & $0(0.0 \%)$ & $2(2.5 \%)$ \\
\hline & & Disagree & $3(6.7 \%)$ & $3(11.5 \%)$ & $0(0.0 \%)$ & $6(7.4 \%)$ \\
\hline & & Agree & $17(37.8 \%)$ & $18(69.2 \%)$ & $6(60.0 \%)$ & $41(50.6 \%)$ \\
\hline & & Strongly Agree & $23(51.1 \%)$ & $5(19.2 \%)$ & $4(40.0 \%)$ & $32(39.5 \%)$ \\
\hline \multirow[t]{4}{*}{ Q2 } & \multirow{4}{*}{$\begin{array}{l}\text { Internship handbook was clear } \\
\text { and very useful. }\end{array}$} & Strongly Disagree & $1(2.2 \%)$ & $0(0.0 \%)$ & $0(0.0 \%)$ & $1(1.3 \%)$ \\
\hline & & Disagree & $2(4.4 \%)$ & $2(7.7 \%)$ & $0(0.0 \%)$ & $4(4.9 \%)$ \\
\hline & & Agree & $27(60.0 \%)$ & $20(76.9 \%)$ & $3(30.0 \%)$ & $50(61.7 \%)$ \\
\hline & & Strongly Agree & $15(33.3 \%)$ & $4(15.4 \%)$ & $7(70.0 \%)$ & $26(32.1 \%)$ \\
\hline \multirow[t]{4}{*}{ Q3 } & \multirow[t]{4}{*}{ Learning outcomes were clear. } & Strongly Disagree & - & - & - & - \\
\hline & & Disagree & $7(15.6 \%)$ & $3(11.5 \%)$ & $1(10.0 \%)$ & $11(13.6 \%)$ \\
\hline & & Agree & $23(51.1 \%)$ & $18(69.2 \%)$ & $5(50.0 \%)$ & $46(56.8 \%)$ \\
\hline & & Strongly Agree & $15(33.3 \%)$ & $5(19.2 \%)$ & $4(40.0 \%)$ & $24(29.6 \%)$ \\
\hline \multirow[t]{4}{*}{ Q4 } & \multirow{4}{*}{$\begin{array}{l}\text { Overall, I was well prepared for } \\
\text { my internship. }\end{array}$} & Strongly Disagree & - & - & - & - \\
\hline & & Disagree & $1(2.2 \%)$ & $2(7.7 \%)$ & $0(0.0 \%)$ & $3(3.7 \%)$ \\
\hline & & Agree & $24(53.3 \%)$ & $16(61.5 \%)$ & $4(40.0 \%)$ & $44(54.3 \%)$ \\
\hline & & Strongly Agree & $20(44.4 \%)$ & $8(30.8 \%)$ & $6(60.0 \%)$ & $34(42.0 \%)$ \\
\hline \multirow{4}{*}{ Q5 } & \multirow{4}{*}{$\begin{array}{l}\text { Internship posting: } \\
\text { My internship supervisor } \\
\text { provided an orientation to the } \\
\text { internship department. }\end{array}$} & Strongly Disagree & $0(0.0 \%)$ & $1(3.8 \%)$ & $0(0.0 \%)$ & $1(1.2 \%)$ \\
\hline & & Disagree & $3(6.7 \%)$ & $6(23.1 \%)$ & $0(0.0 \%)$ & $9(11.1 \%)$ \\
\hline & & Agree & $24(53.3 \%)$ & $12(46.2 \%)$ & $4(40.0 \%)$ & $40(49.4 \%)$ \\
\hline & & Strongly Agree & $18(40.0 \%)$ & $7(26.9 \%)$ & $6(60 / 0 \%)$ & $31(38.3 \%)$ \\
\hline \multirow[t]{4}{*}{ Q6 } & \multirow{4}{*}{$\begin{array}{l}\text { When I started my internship, I } \\
\text { felt accepted and welcomed by } \\
\text { my co-workers. }\end{array}$} & Strongly Disagree & $0(0.0 \%)$ & $1(3.8 \%)$ & $0(0.0 \%)$ & $1(1.2 \%)$ \\
\hline & & Disagree & $3(6.7 \%)$ & $5(19.2 \%)$ & $0(0.0 \%)$ & $8(9.9 \%)$ \\
\hline & & Agree & $17(37.8 \%)$ & $13(50.0 \%)$ & 7 (70.0\%) & $37(45.7 \%)$ \\
\hline & & Strongly Agree & $25(55.6 \%)$ & $7(26.9 \%)$ & $3(30.0 \%)$ & $35(43.2 \%)$ \\
\hline \multirow[t]{4}{*}{ Q7 } & \multirow{4}{*}{$\begin{array}{l}\text { I felt that my presence at the } \\
\text { organization made a positive } \\
\text { contribution to professionals at } \\
\text { internship site. }\end{array}$} & Strongly Disagree & - & - & - & - \\
\hline & & Disagree & $1(2.2 \%)$ & $1(3.8 \%)$ & $0(0.0 \%)$ & $2(2.5 \%)$ \\
\hline & & Agree & $23(51.1 \%)$ & $20(76.9 \%)$ & $8(80.0 \%)$ & $51(63.0 \%)$ \\
\hline & & Strongly Agree & $21(46.7 \%)$ & $4(19.2 \%)$ & $2(20.0 \%)$ & $28(34.5 \%)$ \\
\hline \multirow[t]{4}{*}{ Q8 } & \multirow{4}{*}{$\begin{array}{l}\text { Internship tasks were relevant } \\
\text { to my academic course work. }\end{array}$} & Strongly Disagree & $0(0.0 \%)$ & $1(3.8 \%)$ & $0(0.0 \%)$ & $1(1.2 \%)$ \\
\hline & & Disagree & $7(15.6 \%)$ & $6(23.1 \%)$ & $1(10.0 \%)$ & $14(17.3 \%)$ \\
\hline & & Agree & $25(55.6 \%)$ & $16(61.5 \%)$ & $6(60.0 \%)$ & 47 (58.0\%) \\
\hline & & Strongly Agree & $13(28.9 \%)$ & $3(11.5 \%)$ & $3(30.0 \%)$ & $19(23.5 \%)$ \\
\hline
\end{tabular}


Fayz S. Al Shahry et al.

\begin{tabular}{|c|c|c|c|c|c|c|}
\hline \multirow[t]{4}{*}{ Q9 } & \multirow{4}{*}{$\begin{array}{l}\text { If an appropriate job were open } \\
\text { at this department, I would } \\
\text { apply for it. }\end{array}$} & Strongly Disagree & $2(4.4 \%)$ & $0(0.0 \%)$ & $0(0.0 \%)$ & $2(2.5 \%)$ \\
\hline & & Disagree & $1(2.2 \%)$ & $1(3.8 \%)$ & $1(10.0 \%)$ & $3(3.7 \%)$ \\
\hline & & Agree & $19(42.2 \%)$ & 17 (65.4\%) & $2(20.0 \%)$ & $38(46.9 \%)$ \\
\hline & & Strongly Agree & 23 (51.1\%) & 8 (30.8\%) & 7 (70.0\%) & $38(46.9 \%)$ \\
\hline \multirow[t]{4}{*}{ Q10 } & \multirow{4}{*}{$\begin{array}{l}\text { Overall, my experience as an } \\
\text { intern met my expectations. }\end{array}$} & Strongly Disagree & - & - & - & - \\
\hline & & Disagree & $2(4.4 \%)$ & $3(11.5 \%)$ & $2(20.0 \%)$ & $7(8.6 \%)$ \\
\hline & & Agree & $26(57.8 \%)$ & 17 (65.4\%) & $5(40.0 \%)$ & $48(59.3 \%)$ \\
\hline & & Strongly Agree & $17(37.8 \%)$ & 6 (23.1\%) & $3(30.0 \%)$ & $26(32.1 \%)$ \\
\hline \multirow{4}{*}{ Q11 } & \multirow{4}{*}{$\begin{array}{l}\text { Professional Skills and } \\
\text { Knowledge } \\
\text { I learned new skills and } \\
\text { knowledge in my internship }\end{array}$} & Strongly Disagree & - & - & - & - \\
\hline & & Disagree & $0(0.0 \%)$ & $1(3.8 \%)$ & $0(0.0 \%)$ & $1(1.3 \%)$ \\
\hline & & Agree & $12(26.7 \%)$ & $12(46.2 \%)$ & $3(30.0 \%)$ & $27(33.3 \%)$ \\
\hline & & Strongly Agree & 33 (73.3\%) & $13(50.00 \%)$ & $7(70.0 \%)$ & $53(65.4 \%)$ \\
\hline \multirow[t]{4}{*}{ Q12 } & \multirow{4}{*}{$\begin{array}{l}\text { My internship supervisor } \\
\text { showed interest in my } \\
\text { suggestions/ideas. }\end{array}$} & Strongly Disagree & $0(0.0 \%)$ & $1(3.8 \%)$ & $1(10.0 \%)$ & $2(2.5 \%)$ \\
\hline & & Disagree & $6(13.3 \%)$ & $2(7.7 \%)$ & $0(0.0 \%)$ & $8(9.9 \%)$ \\
\hline & & Agree & $22(48.9 \%)$ & $14(53.8 \%)$ & $4(40.0 \%)$ & $40(49.3 \%)$ \\
\hline & & Strongly Agree & $17(37.8 \%)$ & $9(34.6 \%)$ & $5(50.0 \%)$ & $31(38.3 \%)$ \\
\hline \multirow[t]{4}{*}{ Q13 } & \multirow{4}{*}{$\begin{array}{l}\text { I gained insight into the work } \\
\text { environment and field of my } \\
\text { interest. }\end{array}$} & Strongly Disagree & $1(2.2 \%)$ & $0(0.0 \%)$ & $0(0.0 \%)$ & $1(1.3 \%)$ \\
\hline & & Disagree & $1(2.2 \%)$ & $0(0.0 \%)$ & $0(0.0 \%)$ & $1(1.2 \%)$ \\
\hline & & Agree & 30 (66.7\%) & $18(69.2 \%)$ & 8 (80.0\%) & $56(69.1 \%)$ \\
\hline & & Strongly Agree & $13(28.9 \%)$ & $8(30.8 \%)$ & $2(20.0 \%)$ & $23(28.4 \%)$ \\
\hline \multirow[t]{4}{*}{ Q14 } & \multirow{4}{*}{$\begin{array}{l}\text { I was able to integrate theory } \\
\text { and practice. }\end{array}$} & Strongly Disagree & $1(2.2 \%)$ & $1(3.8 \%)$ & $0(0.0 \%)$ & $2(2.5 \%)$ \\
\hline & & Disagree & $3(6.7 \%)$ & $3(11.5 \%)$ & $0(0.0 \%)$ & $6(7.4 \%)$ \\
\hline & & Agree & $29(64.4 \%)$ & 17 (65.4\%) & 7 (70.0\%) & $53(65.4 \%)$ \\
\hline & & Strongly Agree & $12(26.7 \%)$ & $5(19.2 \%)$ & $3(30.0 \%)$ & $20(24.7 \%)$ \\
\hline \multirow[t]{4}{*}{ Q15 } & \multirow{4}{*}{$\begin{array}{l}\text { My classes became more } \\
\text { meaningful after my } \\
\text { internship. }\end{array}$} & Strongly Disagree & $0(0.0 \%)$ & $1(3.8 \%)$ & $0(0.0 \%)$ & $1(1.3 \%)$ \\
\hline & & Disagree & $4(8.9 \%)$ & $5(19.2 \%)$ & $1(10.0 \%)$ & $10(12.3 \%)$ \\
\hline & & Agree & $25(55.6 \%)$ & 18 (69.2\%) & $3(30.0 \%)$ & $46(56.8 \%)$ \\
\hline & & Strongly Agree & $16(35.6 \%)$ & $2(7.7 \%)$ & $6(60.0 \%)$ & $24(29.6 \%)$ \\
\hline \multirow[t]{4}{*}{ Q16 } & \multirow{4}{*}{$\begin{array}{l}\text { I developed an awareness } \\
\text { of areas in which I needed } \\
\text { growth. }\end{array}$} & Strongly Disagree & $0(0.0 \%)$ & $1(3.8 \%)$ & $0(0.0 \%)$ & $1(1.2 \%)$ \\
\hline & & Disagree & $3(6.7 \%)$ & $0(0.0 \%)$ & $0(0.0 \%)$ & $3(3.7 \%)$ \\
\hline & & Agree & $23(51.1 \%)$ & $17(65.4 \%)$ & $5(50.0 \%)$ & $45(55.6 \%)$ \\
\hline & & Strongly Agree & $19(42.2 \%)$ & $8(30.8 \%)$ & $5(50.0 \%)$ & $32(39.5 \%)$ \\
\hline \multirow[b]{2}{*}{ Q17 } & \multirow{2}{*}{$\begin{array}{l}\text { Evaluation and Feedback } \\
\text { Internship coordinator visited } \\
\text { me at field location for } \\
\text { observation. }\end{array}$} & Yes & $30(66.7 \%)$ & $15(57.7 \%)$ & $7(70.0 \%)$ & $52(64.2 \%)$ \\
\hline & & No & $15(33.3 \%)$ & $11(42.3 \%)$ & $3(30.0 \%)$ & $29(35.8 \%)$ \\
\hline \multirow[t]{2}{*}{ Q18 } & \multirow{2}{*}{$\begin{array}{l}\text { I have the opportunity to freely } \\
\text { evaluate my experience at the } \\
\text { hospital. }\end{array}$} & Yes & $34(75.6 \%)$ & $15(57.7 \%)$ & $7(70.0 \%)$ & $56(69.1 \%)$ \\
\hline & & No & $11(24.4 \%)$ & $11(42.3 \%)$ & $3(30.0 \%)$ & $25(30.9 \%)$ \\
\hline \multirow[t]{2}{*}{ Q19 } & \multirow{2}{*}{$\begin{array}{l}\text { I am asked to prepare a report } \\
\text { at the end of each internship } \\
\text { rotation. }\end{array}$} & Yes & $14(31.1 \%)$ & $12(46.2 \%)$ & $1(10.0 \%)$ & $27(33.3 \%)$ \\
\hline & & No & $31(68.9 \%)$ & $14(53.8 \%)$ & $9(90.0 \%)$ & $54(66.7 \%)$ \\
\hline \multirow[t]{2}{*}{ Q20 } & \multirow{2}{*}{$\begin{array}{l}\text { Meetings were arranged by } \\
\text { my university to reflect and } \\
\text { share my internship experience } \\
\text { throughout the course. }\end{array}$} & Yes & $19(42.2 \%)$ & $9(34.6 \%)$ & $1(10.0 \%)$ & $29(35.8 \%)$ \\
\hline & & No & $26(57.8 \%)$ & $17(65.4 \%)$ & $9(19.0 \%)$ & $52(64.2 \%)$ \\
\hline \multirow[t]{2}{*}{ Q21 } & I was heard and responded & Yes & 37 (82.2\%) & $18(69.2 \%)$ & $9(19.0 \%)$ & $64(79.0 \%)$ \\
\hline & $\begin{array}{l}\text { to when I raised issues about } \\
\text { the internship process with } \\
\text { internship coordinator. }\end{array}$ & No & $8(17.8 \%)$ & $8(30.8 \%)$ & $1(10.0 \%)$ & $17(21.0 \%)$ \\
\hline
\end{tabular}


affect the precision of our estimates in this study. It is worth mentioning that some of the preceptor deviated from the training framework to address more specialized advanced skills or techniques which is match the level of the intern and track them out of the training scope. There was a notable feedback on the divergence of the training content versus the written training manual, since some trainer tends to address a higher level content above the interns level.

\section{CONCLUSION}

We found a high satisfaction rate of OT and PT interns in this study, and higher satisfaction of PT interns compared to OT interns, a regular short term feedback between intern student and their preceptors is of a great importance for student to rectify and maintain focuses on the training framework and avoid expanding to advanced techniques beyond student level will assure better outcomes. It is obvious that a further research can be conducted using the same questionnaire to explore different hospitals in Riyadh and different regions within Saudi Arabia to have an overall picture of satisfaction rate among the PTs and OTs on the national level preceptors must maintain training to the level of the interns.

\section{REFERENCES}

Al-Muhanna F. (2009) Challenges to Saudi medical education in the third Millennium. J Family Community Med. 16 (2):67-69.

Alshomrani Y, Althaqafi M, Albarakati B. (2016) Medical Interns' Learning and Mistreatment Received during the Internship Year. Are They Satisfied? Education 6(1):13-16.

AlThukair D.(2014) Evaluation of the University of Dammam's Compliance with NCAAA Standards of Field Experience and its Impact on Satisfaction. ERIC 1-28.

Berger, Jason (1985) Making an Internship Work. Public Relations Journal 47(4):30- 31

Cheong A, Yahya N, Shen Q, Yen A. (2014) Internship Experience: An In-Depth Interview among Interns at a Business School of a Malaysian Private Higher Learning Institution. Proceedings - Social and Behavioral Sciences 123:333-343.

D'abate C, Youndt M, Wenzel K (1988) Making the Most of an Internship: An Empirical Study of Internship Satisfac- tion. Academy of Management Learning \& Education. 2009; 8(4):527-539.

Daugherty S, Baldwin, Jr D, Rowley B. (1998) Learning, Satisfaction, and Mistreatment During Medical Internship A National Survey of Working Conditions. JAMA Network. 279(15):1194-1199.

Dennis A. (1996) The Benefit of Using College Interns in a Firm. Journal of Accountancy. 181:889-892.

Finucane P, 0'Dowd T. (2009) Working and training as an intern: a national survey of Irish interns. Medical Teacher 27(2):107-113.

Hannon F. (2000) A national medical education needs' assessment of interns and the development of an intern education and training programme. Medical Education. 2000; 34(4):275284.

Nelson A. (1994) Hospitality internships: The effects of job dimensions and supportive relationships on student satisfaction 71-84.

Phua G, Teoh C, Khong L, Baba B, Lim C, Koh W (2017) The Satisfaction and Perception of Intern Pharmacists towards their Training in Government Hospitals in the Northern Region of Malaysia 17 (1) 15 - 23.

Ramus, Erica (1997) Internship Programs from Start to Finish. Folio: The Magazine for Magazine Management 26(6):38-39.

Sasnett B, Ross T. (2016) Maximizing Internship Value by Comparing Student Satisfaction and Program Competencies. Journal of Community Medicine \& Health Education 6 (390)

Seibert J, Sypher B. (1989) The Importance of Internship Experiences to Undergraduate Communication Students. ERIC 1-25.

Serwah A, Sulimani A, Samy W, Serwah M. (2015) Assessment of the level of satisfaction of final years medical students with the clinical training at Taif teaching hospitals, KSA. Journal of Contemporary Medical Education 3(2):64.

Taylor M. (1988) Effects of college internships on individual participants. Journal of Applied Psychology 73(3):393401.

Verney T, Holoviak S, (2009) Winter A. Enhancing the Reliability of Internship Evaluations. Journal of Applied Business and Economics 22-33.

Yafang B, Gongyong F. (2016) A Study on Hospitality Students' Satisfaction towards their Internship: a Case from Hang Zhou, China. 1069-1076.

Wurfel, Walter W. (1985) Well-nurtured Interns can Reap Benefits and Bring Rewards. Public Relations Journal 41(4):37. 